\author{
ADAM BARABASZ, MARCIN PIECHOCKI \\ Poznań
}

\title{
Partnerstwo Wschodnie jako instrument polityki wschodniej UE?
}

Od podpisania Traktatu z Maastricht Unia Europejska była zainteresowana zacieśnieniem relacji ze swoimi najbliższymi sąsiadami. Od 1995 roku rozpoczęła współpracę z krajami basenu Morza Śródziemnego w ramach procesu barcelońskiego ${ }^{1}$. W kolejnych latach rozwinięto szereg inicjatyw w regionie. Współpraca zaowocowała zbliżeniem podmiotów głównie w zakresie handlu i współpracy rozwojowej oraz wspólnej polityki zagranicznej i bezpieczeństwa. Podpisano także umowy stowarzyszeniowe z Tunezją (1995), Marokiem (1995), Jordanią (1997), Autonomią Palestyńską (1997), Egiptem (2001), Libanem (2002), Algierią (2002)2.

Następne lata przyniosły reorientację polityki zagranicznej UE w kierunku wschodnim i południowym. Akcesja 8 nowych krajów Europy Środkowej i Wschodniej oraz Cypru i Malty zrodziła potrzebę wypracowania przez UE nowej, spójnej polityki wobec sąsiadów. 12 maja 2004 roku Komisja Europejska opublikowała komunikat: Europejska Polityka Sąsiedztwa. Został on przyjęty przez Radę Europejską w dniach 17-18 czerwca tego roku. Dokument obejmował trzy grupy krajów:

a) z Europy Wschodniej - Białoruś, Ukrainę, Mołdawię;

b) z Basenu Morza Śródziemnego - Algierię, Egipt, Izrael, Jordanię, Liban, Libię, Maroko, Autonomię Palestyńską, Syrię, Tunezję, utożsamianą od 1995 roku z tzw. procesem bolońskim UE;

c) z południowego Kaukazu - Armenię, Azerbejdżan, Gruzję $e^{3}$.

Do głównych celów EPS zaliczono: promocję wartości UE, dialog polityczny, współpracę na rzecz rozwoju społeczno-gospodarczego, pomoc finansową i techniczną, w celu zbliżenia tych krajów do rynku wewnętrznego Unii, współpracę w dziedzinie wymiaru sprawiedliwości i spraw wewnętrznych, energetyki, transportu, ochrony środowiska, badań i rozwoju, technologii informatycznych ${ }^{4}$. W oparciu o dokument zainicjowano m.in. utworzenie strefy wolnego handlu z Ukrainą oraz budowę centrum

1 Jesienią 1995 roku stolicy Katalonii odbyło się spotkanie piętnastu państw Unii Europejskiej i dwunastu krajów śródziemnomorskich. Podczas konferencji podpisano tzw., „,deklarację barcelońską", w ramach której sformułowano trzy koszyki partnerstwa obejmujące: działania polityczne, gospodarcze i społeczno-kulturalne, zob. szerzej: R. Zięba, Polityka zagraniczna Unii Europejskiej w rejonie śródziemnomorskim, „Przegląd Europejski” 2005, nr 1, s. 103-143.

2 K. Lastawski, Od idei do integracji europejskiej, Warszawa 2004, s. 314.

3 E. Cziomer, Geneza, struktura oraz przestanki wdrażania Partnerstwa Wschodniego Unii Europejskiej w latach 2008-2010, w: Partnerstwo wschodnie wielka szansa dla Europy, red. J. Sawczuk, Poznań-Chorzów 2011, s. 40.

4 J. J. Węc, Polska wobec projektu Partnerstwa Wschodniego, w: Partnerstwo wschodnie wielka szansa dla Europy, red. J. Sawczuk, Poznań-Chorzów 2011, s. 70. 
wizowego Unii Europejskiej w Mołdawii ${ }^{5}$. Państwa członkowskie UE, będąc świadome korzyści głównie gospodarczych wynikających ze współpracy z obszarem poradzieckim, starały się wypracować z sąsiadami korzystną formułę kooperacji.

Przystapienie Bułgarii i Rumunii do Unii Europejskiej w 2007 roku wymusiło potrzebę przesunięcia granic UE do regionu Morza Czarnego. 11 września 2007 roku Komisja Europejska przyjęła komunikat: Synergia Czarnomorska - nowa inicjatywa współpracy regionalnej. Projekt obejmował współpracę państw znajdujących się w obrębie Morza Czarnego: Grecja, Bułgaria, Rumunia, Mołdawia, Ukraina, Rosja, Gruzja, Armenia, Azerbejdżan i Turcja - z UE 6 .

W latach 2006-2008 funkcjonowały różne inicjatywy na rzecz pogłębienia współpracy UE z byłymi republikami radzieckimi (Partnerstwo Wschodnie, Synergia Czarnomorska, Wymiar Północny UE). W 2006 roku prezydencja austriacka zaproponowała pogłębienie współpracy z Ukrainą i Białorusią w ramach polityki energetycznej UE . W 2007 roku pojawiły się dwie inne inicjatywy. Prezydencja niemiecka zaproponowała projekt „EPS plus” [Europejska polityka sąsiedztwa plus], a następnie Polska i Litwa sugerowały pogłębienie wschodniego i południowego wymiaru polityki sąsiedztwa ${ }^{8}$.

Wiosną 2008 roku w Brukseli podczas szczytu ministrów spraw zagranicznych UE przedstawiona została polsko-szwedzka inicjatywa Partnerstwa Wschodniego. Motywem polsko-szwedzkiej koncepcji było m.in.:

- ożywienie wymiaru Europejskiej Polityki Sąsiedztwa w kierunku wschodnim, gdzie perspektywa formalnego członkostwa w UE dla poradzieckich krajów była niezwykle odległa i trudna do sprecyzowania;

- wykorzystanie powyższej inicjatywy w celu pokazania zdolności Polski do aktywnego kształtowania polityki wschodniej UE - Szwecja już od kilku lat akcentowała doniosłą rolę Polski w kreowaniu polityki wschodniej UE;

- konieczność przejścia od ogólnych deklaracji poparcia do konkretnych działań i spełnienia choć części oczekiwań wschodnich sąsiadów Polski (kraje proradzieckie współpracowały z UE w oparciu o ogólne porozumienia podpisane jeszcze w latach 90-tych);

- przeciwdziałanie lansowanej przez francuskiego prezydenta Nicolasa Sarkozy'ego pierwszej wersji Unii Śródziemnomorskiej, które groziło m.in. dużym uszczupleniem środków przeznaczonych dla Partnerstwa Wschodniego, a co najgorsze podziałem Europy na strefy wpływów ${ }^{9}$. W tym miejscu warto nadmienić, że projekt prezydenta Francji w oczywisty sposób przyznawał Paryżowi uprzywilejowaną pozycję. Sarkozy zmierzał do wzmocnienia tradycyjnego kierunku francuskiej polityki zagranicznej, bazował na silnych związkach politycznych i kulturowych z obszarem Afryki Północnej ${ }^{10}$. Idea ta skierowana była głównie do Włoch i Hiszpanii, z aktywności w tym obszarze miały być wykluczone Niemcy.

5 M. Arcipowska, „Biuletyn” PISM 2011, nr 91.

6 T. Kapuśniak, Wymiar wschodni Europejskiej Polityki Sasiedztwa Unii Europejskiej, Warszawa 2010 , s. 33.

7 B. Wojna, M Gwiazdowki, Eastern Partnership: The Opening Report, Warsaw 2009.

8 J. Węc, op. cit., s. 71.

9 E. Cziomer, op. cit., s. 43.

10 J. Sawczuk, Narodziny Partnerstwa wschodniego w świetle gry interesów Francji i Niemiec w UE, w: Partnerstwo wschodnie wielka szansa dla Europy, red. J. Sawczuk, Poznań-Chorzów 2011, s. 80. 
W grudniu 2007 roku, jeszcze przed szczytem Berlin-Paryż, kanclerz Niemiec Angela Merkel odwodziła Sakozy'ego od pomysłu zamykania Unii Śródziemnomorskiej dla innych państw. Sugerowała, że inicjatywa ta podzieli UE w taki sposób, że Niemcy będą patrzyły na wschód, a Francja na południe ${ }^{11}$. Dyplomatyczne wypowiedzi prezydenta Francji zaprzeczające wykluczeniu Niemiec z tego projektu nie uspokoiły Berlina. Pod koniec 2007 roku Niemcy stanęły na czele koalicji członków UE opowiadających się za wspólną, a nie francuską Unią dla Śródziemnomorza. W wyniku tych wydarzeń Paryż odnotował porażkę w dyplomatycznej potyczce z Niemcami, a Unia dla Śródziemnomorza zaczęła ustępować wspieranej przez Niemcy wizji Partnerstwa Wschodniego.

Architekci projektu Partnerstwa Wschodniego - Polska i Szwecja widziały w nim duże korzyści, ale w inny sposób je akcentowały. Polska w doktrynie polityki zagranicznej: nawiązywała do historycznych koncepcji współpracy Polski z najbliższymi sąsiadami (zob. Jerzy Giedrojć i koncepcja ULB) ${ }^{12}$. Dążyła także do zmiany położenia otoczenia geopolitycznego RP poprzez dalsze poszerzenie UE i NATO na wschód, szczególnie w odniesieniu do Ukrainy. Po Pomarańczowej Rewolucji wydawało się, że Ukraina będzie podążać drogą wyznaczoną przez standardy unijne, a Polska może być adwokatem Kijowa na drodze do członkostwa. Po zwycięstwie Wiktora Janukowycza plany zostały na jakiś czas odłożone. Przy takim układzie sił politycznych nie widziano możliwości realizowania ich. Zamierzeniem Polski było także zapewnienie dostępu do surowców energetycznych na Zakaukaziu, co w dobie dyskusji i sporów wewnątrz UE na temat bezpieczeństwa energetycznego wydawało się być roztropnym kierunkiem działań. Ze zrozumiałych względów Polsce zależało na nie ograniczaniu, ale przyznaniu większej roli poradzieckim państwom Europy Wschodniej i Zakaukazia.

W Szwecji idea Partnerstwa Wschodniego nie wzbudzała tak żywego zainteresowania jak w Polsce. Kojarzona była głównie z byłym premierem, konserwatywnym politykiem Carlem Bildtem, który znany był z ostrej krytyki Kremla i który miał osobiste ambicje, aby objąć ważne stanowisko w strukturach UE. W ostatnich latach w działaniach Polski i Szwecji widać było zbieżność ocen, która przekładała się na rozumienie celów Partnerstwa oraz instrumentów niezbędnych do ich realizacji. Rezonans był widoczny podczas konfliktu gruzińsko-rosyjskiego, który był poważnym wyzwaniem dla UE. W tym czasie zarówno Carl Bildt jak i Radosław Sikorski podkreślali, że w następstwie konfliktu gruzińskiego „ciężar zainteresowania UE przesuwa się wyraźnie na wschód, którego stabilność polityczna i ekonomiczna leży w interesie Europy”.

3 grudnia 2008 roku Komisja Europejska przedłożyła w formie komunikatu rozbudowany Program Partnerstwa Wschodniego. Oferta obejmowała m.in. kwestie zawarcia w przyszłości nowych układów stowarzyszeniowych, dalsze powiązania gospodarcze z perspektywą utworzenia strefy wolnego handlu, ułatwienia wizowe, zwiększenie pomocy finansowej, ale bez perspektywy członkostwa w UE.

Treść Komunikatu zaproponowała Rada Europejska na posiedzeniu 19-20 marca 2009 roku. Zbliżenie gospodarcze i polityczne „Partnerów Wschodnich” miało sprowadzać się do następujących deklaracji:

11 Ibidem, s. 81.

12 Zob. szerzej, A. Barabasz, Polacy i Polska wobec idei integracji europejskiej $w$ latach 1915-1957, Toruń 2008, s. 208-212. 
- przywiązania do zasad praworządności państwa;

- poszanowania praw człowieka i podstawowych wolności;

- przywiązania do zasad gospodarki rynkowej i zrównoważonego rozwoju.

Struktura Partnerstwa obejmowała następujące formy instytucjonalizacji współpracy:

- szczyty z udziałem szefów państw i rządów;

- doroczne spotkania MSZ;

- okresowe spotkania Zgromadzenia Parlamentarnego;

- spotkania w ramach platform tematycznych;

- spotkania eksperckie w zależności od potrzeb ${ }^{13}$.

Formy współpracy miały występować w dwóch zakresach:

- dwustronne - wzmocnienie współpracy politycznej poprzez podpisanie układów stowarzyszeniowych oraz bliższa współpraca w zakresie WPBiO, wsparcie reform administracyjnych, ułatwienia w podróżowaniu do krajów UE, bezpieczeństwo energetyczne;

- wielostronne - stworzenie wspólnego forum do wymiany doświadczeń, ułatwienia przyjmowania wspólnych stanowisk, podejmowania działań, dyskusja nad tematami, zapoznawanie partnerów z prawodawstwem i standardami UE ${ }^{14}$.

Co ciekawe, plany wsparcia $\mathrm{PW}$ obejmowały różne projekty i programy współpracy z instytucjami UE, m.in. zwiększenie ich udziału w programie regionalnym INTERREG.

Opracowano także trzy formy długofalowych skoordynowanych działan:

- cztery platformy tematyczne: ds. demokracji, integracji gospodarczej i konwergencji z politykami UE, bezpieczeństwa energetycznego, kontaktów międzyludzkich;

- inicjatywy flagowe: zintegrowany program zarządzania granicami, wsparcie małych i średnich przedsiębiorstw, południowy korytarz energetyczny;

- Forum Społeczeństwa Obywatelskiego: zaangażowanie organizacji pozarządowych dla powodzenia reform $\mathrm{PW}$, monitorowanie działań rządów i administracji w realizacji uzgodnionych celów $\mathrm{PW}^{15}$.

Zakreślone przez Radę Europejską plany współpracy UE z ,partnerami wschodnimi” wydawały się być bardzo ambitne, ale już na początku okazały się trudne do zrealizowania. Sugerowano, że w krajach Partnerstwa łamane są prawa człowieka, a opozycja polityczna jest prześladowana. Podkreślano, że przywódcy tych krajów nie przestrzegają zasad demokracji, a ich gospodarkom daleko do wolnorynkowych standardów.

Podczas wspomnianego szczytu z 19-20 marca 2009 roku, Rada zapowiedziała także inauguracyjny Szczyt Partnerstwa Wschodniego, który rozpoczął się 7 maja 2009 roku w Pradze, podczas prezydencji czeskiej. Polsko-swedzką inicjatywę przyjęto $\mathrm{w}$ formie obszernej deklaracji ${ }^{16}$.

Polsko-szwedzką propozycję w państwach partnerskich przyjęto względnie przychylnie, lecz nieentuzjastycznie. W pełni zadowolony po praskim spotkaniu wydawał się być Michail Sakaszwili. Nazwał on Partnerstwo Wschodnie godną odpowiedzią Europy na wojnę gruzińsko-rosyjska.

13 E. Cziomer, op. cit., s. 47.

14 Ibidem, s. 48.

15 Ibidem, s. 49

16 D. Pszczółkowska, J. Pawlicki, Partnerstwo wschodnie zaczęło się w Pradze, „Gazeta Wyborcza" z 8 maja 2010 r. 
Większość partnerów z Europy Wschodniej akcentowała przede wszystkim korzyści gospodarcze wynikające z tworzenia stref wolnego handlu. Nadzieje wiązano także ze złagodzeniem reżimu wizowego, na który np. wstępnie zgadzała się Warszawa, a stanowczo odmawiały Hiszpania i Niemcy.

Największe zastrzeżenia podczas paryskiego szczytu budziła postawa państw członkowskich UE. Z przywódców największych krajów przyjechała tylko Angela Merkel. Nie było Gordona Browna i José Luisa Rodrigueza Zapatero, Francję reprezentował premier François Fillon, a Silvio Berlusconi wymówił się kłopotami rozwodowymi i przysłał ministra pracy. Austrię reprezentował ambasador przy UE ${ }^{17}$. Zaniepokojenie projektem wyraziła również Rosja, która inaugurację szczytu uznała za ingerowanie $\mathrm{w}$ jej sprawy wewnętrzne i naruszenie strefy interesów geopolitycznych ${ }^{18}$.

Pomimo widocznego braku wiary rządów unijnych w realizację idei Partnerstwa, szef dyplomacji polskiej Radosław Sikorski nie krył zadowolenia z oficjalnej akceptacji dla polskiego pomysłu: „skromność nie pozwala, ale większość mówców chwaliła tę polsko-szwedzką inicjatywę. Chwalą ją już media zachodnie, myślę, że możemy powiedzieć, że jest to dzień polskiego sukcesu w Unii Europejskiej, dzień w którym cała UE uchwaliła, zatwierdziła polską inicjatywę ${ }^{\text {"19 }}$. Sugerowano, że wraz ze zmianą polityki wschodniej Unii Europejskiej zrodziła się szansa na wzmocnienie pozycji strategicznej Polski jako kraju łączącego zachód ze wschodnimi sąsiadami ${ }^{20}$. Polska miała zostać ambasadorem krajów wschodnich i wspierać ich starania o zbliżenie się do standardów europejskich: demokracji i zasad wolnego rynku oraz wspierać restrukturyzację ich systemów gospodarczych.

Jak zauważył znany publicysta tygodnika „Polityka”, inauguracja Partnerstwa Wschodniego przebiegała w niełatwej atmosferze. Wizja wspólnej europejskiej polityki sąsiedztwa utrwaliła podziały między państwami ${ }^{21}$. Choć Niemcy wspierały Polskę w promowaniu projektu, to tak naprawdę same aspirowały do tego, aby zostać animatorem polityki wschodniej UE. Francja w dalszym ciągu nie ukrywała większego zainteresowania projektem śródziemnomorskim aniżeli ideą partnerstwa i akcentowała zabezpieczenie swoich interesów w Afryce Północnej. Nie wspominając o chęci zacieśnienia współpracy na linii Paryż-Berlin-Moskwa, co mogłoby godzić w interesy polskie. Holendrzy, Hiszpanie i Portugalczycy akcentowali, że w Partnerstwie powinny uczestniczyć Rosja, Turcja i inne kraje. Z kolei Rosja nie tylko nie wyraziła zainteresowania projektem, ale krytykowała UE, za to, że podjęła próbę stworzenia strefy wpływów w regionie. Kreml podejrzliwie spoglądał na wszystkie inicjatywy, w które

17 Por. D. Pszczółkowska, J. Pawlicki, Moda na wschód minęła, „Gazeta Wyborcza” z 8 maja 2010 r. Zob. także, http://www.wprost.pl/ar/160644/UE-powolala-Partnerstwo-Wschodnie/ (data dostępu 10.11.2012).

${ }_{18} \mathrm{http} / / /$ swiat.newsweek.pl/unia-europejska-nadepnela-na-odcisk-rosji,39215,1,1.html (data wejścia na stronę 10.11.2012).

$19 \mathrm{http} / /$ polska.newsweek.pl/sikorski- to-jest-dzien-polskiego-sukcesu,39206,1,1.html (data wejścia na stronę 10.11.2012).

${ }^{20} \mathrm{http}: / /$ www.stosunkimiedzynarodowe.pl/partnerstwo-wschodnie-szanse-i-zagro\% $\% 5 \% \mathrm{BCe}$ nia-dla-polski (data wejścia na stronę (7.11.2012).

21 A. Szostkiewicz, Zaczęło się w Pradze, „Polityka z 5 maja 2009 r. 
włączane były byłe republiki radzieckie. Duże nadzieje z rozwojem inicjatywy wiązano z polską prezydencją.

15 marca 2011 roku przyjęto sześciomiesięczny program polskiej prezydencji w Radzie Unii Europejskiej w II połowie 2011 roku. Przedłożony on został przez Mikołaja Dowgielewicza, pełnomocnika rządu ds. przygotowania organów administracji rządowej i sprawowania przez RP przewodnictwa w Radzie UE. Wyznaczono trzy główne cele polityczne Unii Europejskiej, które miały wprowadzić Unię na tory rozwoju polityczno-gospodarczego. Jeden z priorytetów nazwano: Europa korzystajaca na otwartości. Zakładał on wsparcie polityki zagranicznej i bezpieczeństwa Unii Europejskiej. Aktywność Polski sprowadzać się miała do wspierania zasad wolnego handlu w kontaktach z państwami objętymi programem Partnerstwo Wschodnie, poszerzając rynek, grono konsumentów oraz realizując tym samym założenia Europejskiej Polityki Sąsiedztwa: „W ramach Partnerstwa Wschodniego będziemy dążyć do: zawierania umów stowarzyszeniowych i tworzenia stref wolnego handlu (chodzi m.in. o finalizację lub znaczący postęp w negocjacjach z Ukrainą i Mołdową); postępów w liberalizacji wizowej; pogłębiania współpracy sektorowej” - zapowiadali urzędnicy w Kancelarii Premiera Rady Ministrów ${ }^{22}$.

Podczas polskiej prezydencji pozytywne akcenty na rzecz projektu Partnerstwa pojawiły się także w Programie Kulturalnym Polskiej Prezydencji. Instytut im. Adama Mickiewicza, który odpowiadał za opracowanie i realizację Zagranicznego Programu Kulturalnego Polskiej Prezydencji ${ }^{23}$, jeszcze przed objęciem przez Polskę przewodnictwa stworzył specjalny portal internetowy nawiązujący do hasła polskiej prezydencji. Jego głównym zadaniem było promowanie twórców polskiej kultury i dostarczanie wielu rzetelnych informacji na temat wydarzeń kulturalnych w kraju i za granica. Portal zawierał również biogramy twórców, eseje, opisy dzieł itp. ${ }^{24}$

Wyrazem solidarności z krajami Partnerstwa było zaaranżowanie projektu I, Culture Orchestra, inicjatywy młodych muzyków z Armenii, Azerbejdżanu, Gruzji, Ukrainy, Białorusi, Mołdawii i Polski. Za pośrednictwem muzyki chcieli oni promować porozumienia ponad podziałami kulturowymi. Zasadniczym celem wystawy było pokazanie sztuki artystów pochodzących głównie z Azerbejdżanu, Armenii, Białorusi, Ukrainy, Gruzji i Mołdowy. Pomysł ten wpisywał się w jeden z głównych priorytetów polskiego przewodnictwa, jakim była idea Partnerstwa Wschodniego. Przesłanie tej inicjatywy zawierało się w słowach znanego polskiego publicysty Edwina Bendyka, który w uczuciu miłości widział główny budulec stosunków międzyludzkich, tym samym międzysąsiedzkich. Natomiast Polska jako pomysłodawca idei Partnerstwa, podczas sprawowania prezydencji wyrastała na głównego patrona i opiekuna państw aspirujących do członkostwa w UE.

Centralnym punktem polskiego przewodnictwa w Radzie UE miał być Szczyt Partnerstwa Wschodniego w Warszawie. Trudno było oczekiwać spektakularnego sukcesu, który posunąłby do przodu ten ambitny projekt, bowiem jego największą słabością był od początku brak obietnicy członkostwa. To z kolei czyniło go mało atrakcyjnym dla

${ }^{22}$ http://prezydencjaue.gov.pl/obszary-przygotowa/programowanie (data wejścia na stronę 25 sierpnia 2011).

${ }^{23} \mathrm{http} / /$ mkidn.gov.pl/pages/pl2011/pl/agora/prezydencja.php (data wejścia na stronę 25 sierpnia 2011).

24 www.culture.pl (data wejścia na stronę 15 sierpnia 2011). 
państw, dla których, choćby odległa, perspektywa akcesji mogła stać się impulsem modernizacyjnym. Brak obietnicy członkostwa sprawia, że każde państwo wykorzystuje Partnerstwo do swoich celów. Widać to zwłaszcza w odniesieniu do Białorusi, której włączenie do programu można zresztą interpretować jako formę uznania reżimu Aleksandra Łukaszenki, a przynajmniej tak na arenie wewnętrznej czyni prezydent. Wpływ społeczności międzynarodowej na to państwo pozostaje, mówiąc oględnie, ograniczony. Również Ukraina, która wynegocjowała umowę stowarzyszeniową nie może na razie liczyć na jej rychłe podpisanie. Będzie to zależeć od przestrzegania europejskich wartości, jak stwierdził Jose Manuel Barroso. Największe kontrowersje budzą procesy wytoczone Julii Tymoszenko i Jurijowi Łucence. Zdaniem Przewodniczącego Komisji Europejskiej, były one niesprawiedliwe i utrudniły zdobycie mandatów poselskich. Również Gruzja, która cieszy się dużą sympatią Polaków, ma problemy z przestrzeganiem standardów demokratycznych. Prezydent Micheil Saakaszwili, do niedawna postrzegany jako gwarant zbliżenia z Zachodem, coraz częściej oceniany jest przez pryzmat autorytarnych skłonności, na co zwracała uwagę choćby Amnesty International $^{25}$. Armenia i Azerbejdżan toczą konflikt o Górski Karabach, jednak to drugie państwo, zwłaszcza prezydent Ilham Alijew, może liczyć na większą wyrozumiałość w Europie Zachodniej z uwagi na zasoby surowców energetycznych ${ }^{26}$. W przypadku nazbyt intensywnego upominania się o zachowanie standardów demokratycznych (zniesienie ograniczeń liczby kadencji dla urzędu prezydenta, sposób przeprowadzenia wyborów w 2010 roku), Azerbejdżan może skierować swoją uwagę na inne państwa, które chętnie zapłacą za jego surowce. Liderem przemian pozostaje Mołdawia, jednak na jej ocenie musi ciążyć spór toczony z Republiką Naddniestrzańską.

W przygotowanym przez Polski Instytut Spraw Międzynarodowych dokumencie „Partnerstwo Wschodnie - raport otwarcia”, analizie poddano państwa objęte Partnerstwem. Przeczytać tam można, że Armenia uznaje członkostwo w Unii Europejskiej za strategiczny wybór, podobnie jak w przypadku Azerbejdżanu, choć autorzy raportu uznają to jedynie za deklaracje - na przeszkodzie stoi autorytarny ustrój. W Gruzji najmocniej akcentuje się wolę większego zaangażowania UE w rozwiązywanie kaukaskich konfliktów, bezpieczeństwa energetycznego, tranzytu surowców i transportu. Mołdawia z kolei liczy na pomoc UE w sporze z nieuznawaną Republiką Naddniestrzańską oraz fundusze unijne, jednak do samej inicjatywy nie podchodzi bezkrytycznie. W przypadku Ukrainy, jej władze chętnie podkreślają swoją europejską tożsamość kulturową i konieczność określenia perspektywy członkostwa. Słowem, państwa objęte Partnerstwem realizują lub chcą realizować w jego ramach swoje cele, wszystkie również mają problemy z wypełnianiem standardów demokratycznego państwa ${ }^{27}$.

25 Zobacz: Georgia: Authorities must stop violence against opposition ahead of election, 20 July 2012, http://www.amnesty.org/en/library/asset/EUR56/003/2012/en/af08c481-83ec-4f2c-846c-b23848300b87/ eur560032012en.html (dostęp: 2 września 2012).

${ }^{26}$ Ropociagg Baku-Tbilisi-Ceyhan w przyszłości ma zostać przedłużony i dostarczać surowiec do Europy Środkowej. Z kolei Gazociąg Południowokaukaski zostanie połączony z gazociagiem Nabucco. Wystarczy również wspomnieć szczyt energetyczny w Baku czy wizytę prezydenta Alijewa w Polsce i serdeczne przyjęcie przez Lecha Kaczyńskiego.

27 Według „Democracy Index 2011” opracowanego przez „The Economist”, w grupie demokracji określanych mianem niedoskonałych znalazły się: Mołdawia (pozycja 64), Ukraina (pozycja 79), 
Realizacji Partnerstwa Wschodniego nie sprzyjał moment jego rozpoczęcia, który zbiegł się z kryzysem gospodarczym. Trudno oczekiwać zgody państw członkowskich na łożenie dodatkowych środków na „eksport demokracji” poza wschodnie granice Unii Europejskiej, jeśli wspomaganie budżetów dotkniętych kryzysem państw unijnych budzi kontrowersje. Solidarność padła ofiarą kryzysu i podobnie może stać się z forsowanym przez Polskę i Szwecję projektem. Większym problemem dla Berlina czy Paryża jest sytuacja w Grecji, Hiszpanii czy Portugalii, nie jakość demokracji w Azerbejdżanie. Ofiarą kryzysu jest zwłaszcza gospodarczy komponent Partnerstwa Wschodniego. Warto też pamiętać, że wschodni wymiar Europejskiej Polityki Sąsiedztwa nie jest uznawany przez wszystkie państwa za priorytetowy, jak czyni to Polska, widząc w tym szansę na rozszerzenie. Wystarczy wspomnieć choćby francuską propozycję Unii dla Morza Śródziemnego.

Wszystkie te elementy pozwalały przypuszczać, że warszawski szczyt (29-30 września 2011 r.) nie będzie przełomowy. Pokazał on rozbieżności pomiędzy członkami UE a państwami objętymi Partnerstwem. Zamiast prezydenta Łukaszenki zaproszono ministra spraw zagranicznych, Siarhija Martynau, który jednak z zaproszenia nie skorzystał, wysyłając ambasadora w Polsce. Ostatecznie jednak Białorusi nie reprezentował nikt. Podczas szczytu przyjęto dwie deklaracje końcowe, jednej z nich, dotyczącej sytuacji w Białorusi nie podpisali przedstawiciele państw Partnerstwa. Podobne kontrowersje podczas szczytu budziła sprawa Julii Tymoszenko.

Wśród reakcji na polską prezydencję znaleźć można było takie, które wskazywały, że szczyt Partnerstwa Wschodniego nie przekonał państw Europy Wschodniej do zmian politycznych, które miały stać się warunkiem członkostwa w Unii Europejskiej ${ }^{28}$. W maju 2011 roku Catherine Ashton przedstawiła tę zasadę wprost: pieniądze za postępy w demokracji. Nicu Popescu i Andrew Wilson w raporcie „Turning presence into power: lessons from the Eastern Neighbourhood", przygotowanym dla Europejskiej Rady Stosunków Międzynarodowych, ostrzegają że wysiłki na rzecz demokratyzacji państw objętych Partnerstwem nie przyniosły efektów. Może to w przyszłości doprowadzić do wydarzeń znanych już z Bliskiego Wschodu czy Afryki Północnej ${ }^{29}$. Autorzy opracowania zaznaczają że choć jeszcze nigdy w historii Unia Europejska nie zaznaczyła tak mocno swojej obecności w tych państwach, to nie przekłada się to na realne skutki.

W polityce wewnętrznej ocena prezydencji była sądem nad gabinetem Donalda Tuska i przebiegała według linii bieżących sporów politycznych. Wśród ważnych akcentów należy podkreślić polską propozycję „pakietu modernizacyjnego” skierowanego do Białorusi. Według zapewnień premiera Donalda Tuska obejmuje on pełną amnestię, rehabilitację osób aresztowanych po wyborach, rozpoczęcie rozmów z opozycją oraz przeprowadzenie wyborów według standardów OBWE. Dopóki jednak władzom Białorusi takie działania nie będą się opłacać politycznie lub gospodarczo, re-

Gruzja (pozycja 102), Armenia (pozycja 111), wśród reżimów autorytarnych znalazły się: Białoruś (pozycja 139) i Azerbejdżan (pozycja 140)

28 Zob. C. Arvidsson, Hopp om mer Europa för det nya Östeuropa, „Svenska Dagbladet” z 3 października 2011 r., http://www.svd.se/opinion/ledarsidan/hopp-om-mer-europa-for-det-nya-osteuropa_6519090.svd (dostęp: 2 września 2012).

${ }^{29} \mathrm{http}: / /$ www.ecfr.eu/page/-/ECFR31_ENP_AW.pdf, dostęp: 2 września 2012. 
alizacja pakietu będzie stała pod znakiem zapytania. Szef polskiego rządu podkreślił również, że udało się zakończyć rozmowy stowarzyszeniowe z Ukrainą oraz rozpocząć z Gruzją i Mołdawią. Wśród pozytywnych efektów szczytu można wskazać również obietnice ruchu bezwizowego dla państw, które spełnią stawiane im w tym zakresie wymogi $^{30}$ oraz deklarację utworzenia w Warszawie Akademii Administracji Publicznej Partnerstwa Wschodniego, która ma wspierać procesy demokratyczne w sześciu państwach objętych Partnerstwem. Na szczycie nie mogło zabraknąc kurtuazyjnych deklaracji politycznych, jak te, które padły z ust Hermana van Rompuy`a i Jose Manuela Barroso, a dotyczyły znaczenia zaangażowania Polski w sprawy kontaktów z wschodnimi partnerami oraz wzrostu nakładów na Partnerstwo Wschodnie.

Na ocenie szczytu i polskiej prezydencji z pewnością zaważył kryzys ekonomiczny w strefie euro, który zdominował debatę publiczną w tym czasie. Sytuację dodatkowo utrudniał fakt, że Polska nie jest jej członkiem. Chociaż w obszarze Partnerstwa Wschodniego trudno wskazać postęp czy spektakularny sukces, raczej można mówić o pewnym impasie, to jednak należy podkreślić próbę podtrzymania zainteresowania UE sytuacją w państwach, które dla większości jej obywateli są nieznane, by nie powiedzieć odległe kulturowo. Nie można przecenić znaczenia promowania wartości demokratycznych w państwach, w których nie uda się stworzyć jej mechanizmów na wzór zachodnioeuropejski w przeciągu kilku lat. Takie procesy przebiegają niemalże niezauważalnie, dokonywanie oceny Partnerstwa Wschodniego jest dzisiaj nazbyt pochopne, bowiem potrzebna jest dłuższa perspektywa, by móc zauważyć skuteczność podjętych w jego ramach działań.

Niewiele mogła tu zmienić Polska podczas Prezydencji, bowiem Partnerstwo Wschodnie jest obciazżone grzechem pierworodnym - jego rodzice nie wiedzieli i nie wiedza, czym ma ono być. Czy ma być projektem przygotowującym kolejne państwa do akcesji, czy może raczej powinna być instrumentem służącym eksportowi demokracji poza wschodnie granice? Może jest to projekt zapewniający bezpieczeństwo, w tym energetyczne? Efekty polskiej prezydencji w obszarze Partnerstwa Wschodniego są w większości od Polski niezależne. Najpierw Unia Europejska powinna precyzyjniej określić, czego oczekuje od realizacji tego projektu i co może zaoferować w zamian. Nietrudno bowiem znaleźć państwa, które zaoferują podobne korzyści, ale nie będą stawiały wymogów dotyczących demokratycznych reform. Niepokojący powinien być widoczny już spadek poparcia dla członkostwa w Unii Europejskiej, jaki notowany jest w państwach Partnerstwa. Jego podniesienie byłoby możliwe, gdyby tylko udało się złagodzić reżimy wizowe, które są przeszkodą dla obywateli, nie dla państw. Nicu Popescu i Andrew Wilson już wcześniej zwracali uwagę, że oferta unijna musi konkurować z Rosją która również zabiega o wpływy w regionie. Tymczasem Bruksela nie paliła się do działań w czasie wojny w Gruzji czy podczas konfliktów gazowych z Rosją ${ }^{31}$.

${ }^{30}$ Najbliżej zniesienia obowiązku wizowego są Ukraina i Mołdawia, zob. szerzej: M. Jaroszewicz, Niemożliwe uczynić możliwym. Perspektywy ruchu bezwizowego pomiędzy UE a wschodnimi partnerami, „Punkt widzenia” 2012, nr 27, Warszawa 2012.

31 N. Popescu, A. Wilson, The limits of enlargements-lite: European and Russian power in the troubled neighbourhood. Published on 16 June 2009, zobacz: http://ecfr.eu/page/-/ECFR14 The Limits_of_Enlargement-Lite._European_and_Russian_Power_in_the_Troubled_Neighbourhood.pdf, dostęp: $\overline{2}$ września 2012. 
Z pewnością warto kontynuować działania na szczeblu obywatelskim zgodnie z tym, co 28 listopada 2011 roku, mówił minister spraw zagranicznych, Radosław Sikorski podczas Forum Społeczeństwa Obywatelskiego Partnerstwa Wschodniego w Poznaniu. Podkreślił on wówczas, że Partnerstwo to nie tylko porozumienie pomiędzy rząami, ale także współpraca parlamentarna, samorządowa, forum biznesowe oraz nie mniej ważny wymiar obywatelski. Zaznaczył, jak ważna jest ta kwestia dla jego rządu, stąd starania o ruch bezwizowy. Według zapewnień ministra, Polska wydawała więcej wiz obywatelom państw należących do Partnerstwa niż inne państwa unijne łącznie. Właśnie taki „obywatelski wymiar” Partnerstwa powinien być najważniejszy dla Unii Europejskiej, która powinna potraktować go jako pracę u podstaw, która w przyszłości zaowocuje nowoczesnymi społeczeństwami państw Partnerstwa. Dwa miesiące wcześniej podczas warszawskiej konferencji „Partnerstwo Wschodnie: w kierunku europejskiej wspólnoty demokracji, dobrobytu i silnego społeczeństwa obywatelskiego", która towarzyszyła szczytowi Partnerstwa Wschodniego, minister otwierając debatę zaznaczył, że choć Partnerstwo nie jest projektem geostrategicznym, jego wypełnienie będzie miało konsekwencje geopolityczne. Szczyt, jako najważniejszy akcent polskiej prezydencji, jest wyraźnym sygnałem, że Polska pozostaje adwokatem rozszerzenia UE na wschód co potrafi myśleć w dalszej perspektywie niż kilku lat.

\section{Summary}

\section{The Eastern Partnership as an element of the European Union's Eastern policy}

Established on the initiative of Poland and Sweden, the Eastern Partnership encompasses six states located in the territory of the former USSR, namely Armenia, Azerbaijan, Georgia, Moldova, Ukraine and Belarus. The program was officially initiated in 2009 by offering its members such solutions as softening visa restrictions, the establishment of free trade zones and signing association agreements. One of the priorities of the Polish Presidency, the Eastern Partnership culminated in the summit held in Warsaw on September 29-30, 2011. While Poland sees this project as an opportunity for further enlargements, other member states are not unanimous about what character it should have. Should the Eastern Partnership constitute the eastern dimension of the European Neighborhood Policy, or just the advancement of democratic values without promising EU membership in return for their implementation. This influences the assessment of the Eastern Partnership upon its third year of operation, and of the activities of the Polish Government during the Presidency. Although cooperation between the EU and the countries of the Eastern Partnership was not significantly advanced, Donald Tusk's Government succeeded in maintaining the EU's interest in this topic among member states otherwise engrossed in the eurozone crisis. 